\title{
Neurocognitive functions evaluation by the neuropsychological NEUROPSI battery in patients attending "AA" by drug and alcohol consumption
}

\section{Evaluación de las funciones neurocognitivas mediante la batería neuropsicológica NEUROPSI en pacientes que asisten a "AA" por consumo de drogas y alcohol}

SHADE-CASAS, Helue $\dagger$, ONTIVEROS-VARGAS, Angel Adrian, HERRERA-VARGAS, Isela Vanessa and SALAS-NAME, Sagrario Lizeth

Universidad Juárez del Estado de Durango, Faculty of Psychology and Human Communication Therapy, Mexico.

ID $1^{\text {er }}$ Author: Helue, Shade-Casas / ORC ID: 0000-0002-4070-5537, Researcher ID Thomson: AAU-9263-2021, CVU CONACYT ID: 1144336

ID $1^{\text {er }}$ Co-author: Angel Adrian, Ontiveros-Vargas / ORC ID: 0000-0003-1321-0990, Researcher ID Thomson: 3055407 CVU CONACYT ID: 1003209

ID $2^{\text {er }}$ Co-author: Isela Vanessa, Herrera-Vargas / ORC ID: 0000-0002-9154-6978, Researcher ID Thomson: X-33142018, CVU CONACYT ID: 954357

ID $3^{\text {er }}$ Co-author: Sagrario Lizeth, Salas-Name / ORC ID: 0000-0002-1282-626X, Researcher ID Thomson: X-9347-2018, CVU CONACYT ID: 639389

DOI: $10.35429 / \mathrm{JOHS} .2021 .25 .8 .6 .16$

Received July 15, 2021; Accepted December 30, 2021

\begin{abstract}
Neurocognitive functions are indispensable faculties for daily, social and working life. Objective: Prevalence of altered cognitive functions in patients recovering from drug addiction and alcoholism using the Neuropsychological Battery NEUROPSI. Methodology: exploratory, non-experimental, observational research based on the Neuropsi brief neuropsychological assessment instrument in Spanish. Contribution: in a sample of 20 participants, the following results were obtained: $60 \%$ of the population studied showed alterations in neurocognitive functions, $15 \%$ showed mild alterations, $25 \%$ showed noderate alterations and the other $20 \%$ showed severe alterations. On the other hand, the population within normal parameters $(40 \%)$ presented low scores in reading comprehension, attention and concentration.
\end{abstract}

Neurocognitive functions, Neuropsychological evaluation, Neuropsi, Addictions

\section{Resumen}

Las funciones neurocognitivas son facultades indispensables para la vida cotidiana, social y laboral.

Objetivo: Identificar la prevalencia de las funciones cognitivas alteradas en pacientes en recuperación por drogadicción y alcoholismo mediante la Batería Neuropsicológica NEUROPSI. Metodología: investigación de tipo exploratorio, no experimental, observacional con base al instrumento de evaluación neuropsicológica breve en español Neuropsi. Contribución: en una muestra conformada por 20 participantes se obtuvieron los siguientes resultados, el 60 $\%$ de la población estudiada presenta alteraciones en las funciones neurocognitivas, el $15 \%$ presenta alteración leve, el $25 \%$ alteración moderada y el otro $20 \%$ alteración severa. Por otra parte, la población que se encuentra dentro de los parámetros normales (40\%), presentan puntajes bajos en comprensión lectora, atención y concentración.

Funciones neurocognitivas, Evaluación neuropsicológica, Neuropsi, Adicciones

Citation: SHADE-CASAS, Helue, ONTIVEROS-VARGAS, Angel Adrian, HERRERA-VARGAS, Isela Vanessa and SALAS-NAME, Sagrario Lizeth. Neurocognitive functions evaluation by the neuropsychological NEUROPSI battery in patients attending "AA" by drug and alcohol consumption. Journal of Health Sciences. 2021. 8-24:6-16.

$\dagger$ Researcher contributing as First Author 


\section{Introduction}

According to the National Multiple Sclerosis Society, (sf) cognition, or cognitive function, is called the ability to learn and remember information, with which thanks to this ability we can organize, plan and solve problems and on the other hand it also allows us to concentrate, maintaining and distributing attention as the case may be, for example, when studying or being in a class, it is also the ability to understand and use the language of a mere adequate, recognize or correctly perceive the environment and perform calculations among other functions.

As mentioned by the care corner, cognitive functions are the mental processes that allow us to do countless things, for example, right now while you read, several of them are used. Our cognitive abilities are abilities that our brain has to be able to function and work with the information that we acquire.

The functions mentioned above play a very important role in our lives to be able to carry out different daily tasks such as reading an advertisement, doing the calculations to know how much I have to pay, the attention and concentration we need to study or perform any task, among other cognitive functions such as orientation, memory and language. Together, all these functions help us to have a better quality of life.

Since these functions are of utmost importance for our lives, the question arises whether or not they are altered by drug and alcohol consumption, and to what extent, hence the objective of this research, which is to evaluate cognitive functions using a battery. short neuropsychological, NEUROPSI, which is easy to apply and very comprehensive to assess neurocognitive functions.

To carry out this evaluation, groups of Alcoholics Anonymous were consulted, where patients of different ages from 20 years to 69 years and also of different school grades and even some without any school grade were evaluated.
In 2004, Franco V. mentions that the use and dependence of psychoactive substances represent a significant factor in the increase in the total burden of disease worldwide. The World Health Report (WHO 2002) established that $8.9 \%$ of the total burden of disease is attributed to the use of psychoactive substances, $4.0 \%$ associated with tobacco, $4.1 \%$ with alcohol and $0,8 \%$ to illicit drugs. In many countries, the impact of the use and dependence of psychoactive substances is related to a wide range of health problems and social exclusion, which contribute to the expansion of the burden of disease.

\section{Justification}

It is convenient to carry out this research since the field of work of a Human Communication Therapist could be expanded since it is not only involved in processes of rehabilitation or habilitation of language and learning in infant patients, but also in neurocognitive processes in adult patients. Just as mentioned by the Luis Guillermo Ibarra Ibarra National Rehabilitation Institute in 2017 "Human Communication Therapy is in charge of interacting with the multidisciplinary team, identifying and rehabilitating the processes and pathologies of Human Communication in its four spheres: hearing, language, learning, voice, speech and swallowing through playful teaching materials. However, it does not mention neurocognitive processes as an area of rehabilitation.

Also because there is a large population addicted to both drugs and alcohol and it has a lot of potential in terms of the information that will be obtained. (WHO, 2019).

This research will serve to know the areas affected at a cognitive level thanks to the use and abuse of drugs and alcohol, specifically speaking about cognitive functions.

What is expected to change with this research is not only to give importance to the psychological problems that cause the use and abuse of toxic substances but also to the cognitive part that they affect, then it is observed that there is no one in charge of the cognitive part that they affect drugs in the rehab program. 
According to the Youth Integration Centers in 2018 in its treatment and rehabilitation program it has a team of experts in the treatment of addictions, from the disciplines Medicine, Social Work, Psychology and nursing in the case of requiring hospitalization, trained to provide support, counseling and treatment to people who have problems with the use of alcohol, tobacco and other drugs.

This research can be helpful both for people in recovery, as well as those vulnerable to substance use in secondary or high school grades on the subject of information, as well as for health professionals interested in this topic.

\section{Problem}

The harm caused by drugs is a problem on a social as well as a personal level in each of the different aspects of the two areas. It is a topic of utmost importance since it talks about a problem that for the person who suffers it can be a limitation for their academic, social and daily life (Secretary of Health, 2017).

Drug use can have serious consequences for the future, both for a young person and for a young adult or an elderly person, since drugs can alter the way the brain works due to the different components of drugs.

It is very important to make people aware of the cognitive damage caused by drugs since they usually start their use at an early age in which they are not fully informed about what drugs can cause to their body and the complications that can be have long-term (American Psychiatric Association, 2013).

\section{Hypothesis}

$\mathrm{H}_{0}$ : "Alcoholism and drug addiction alter neurocognitive functions"

$\mathrm{H}_{\mathrm{i}}$ : “Alcoholism and drug addiction do not alter neurocognitive functions.

\section{Objectives}

\section{General objective}

To determine the prevalence of altered cognitive functions in patients recovering from drug addiction and alcoholism using the Neuropsychological Battery NEUROPSI.

\section{Specific objectives}

- Identify the current state of neurocognitive functions using Neuropsi in patients with alcohol dependence according to the DSM-V classification.

- Identify the current state of neurocognitive functions through Neuropsi in patients with cocaine dependence according to the DSM-V classification.

- Identify the current state of neurocognitive functions through Neuropsy in patients with methamphetamine dependence according to the DSM-V classification.

Identify the current state of
neurocognitive functions through
Neuropsi patients with cannabis
dependence according to the DSM-V
classification.

\section{Theoretical framework}

\section{Background}

Alcoholism according to the WHO (1992), consists of a prolonged excessive consumption of alcohol with dependence on it. It is a chronic disease produced by the uncontrolled consumption of alcoholic beverages,

In 2019, NIDA concluded that drug addiction is a chronic disease characterized by compulsive or uncontrollable drug seeking and use despite the damaging consequences that it entails and the changes it causes in the brain, which can be long-lasting.

According to the World Health Organization (WHO, 2019), there are 3 million deaths worldwide each year due to the harmful consumption of alcohol, which represents $5.3 \%$ of all deaths. 
Harmful use of alcohol is a causal factor in more than 200 diseases and disorders, overall $5.1 \%$ of the global burden of disease and injury is attributable to alcohol use.

According to the Government of Mexico (2019) the World Report on Drugs 2019, prepared by the United Nations Office on Drugs and Crime in Mexico (UNODC for its acronym in English), among the results highlights that about 271 million of people in the world used drugs in the last year, which represents 5.5 percent of the population aged 15 to 64 years, and 31 million presented some disorder.

The results of the Ministry of Health (2017) indicate that according to the national survey in Mexico on drug, alcohol and tobacco consumption from 2016-2017, it was found that in a total population between 12 and 64 years of age, $71 \%$ have consumed alcohol sometime in life.

According to the national survey in Mexico on the consumption of drugs, alcohol and tobacco from 2016-2017, it was found that in a total population of 12 to 64 years of age $10.3 \%$.

According to Valdevila, F 2020 there is deterioration in attention, memory, language and other mental functions in adults of both sexes, related to drug and alcohol consumption, a greater deficit is found in subjects with a longer duration of alcohol consumption or cannabis.

\section{Neurocognitive functions}

To be able to carry out any activity, be it reading a book, listening to music, watching a movie, etc. Cognitive processes are needed which are considered as mechanisms, abilities or skills which are used at the time of performing any activity described above, these processes are also used in order to acquire or recover some prior knowledge and the processes that are carried out out are attention, memory, language and executive functions (Ríos, et al. 2017).
According to Ostrosky et al. In 2012 the orientation is the awareness of oneself in relation to its surroundings, thanks to this the integration of attention, perception and memory is necessary. A deterioration in the perceptual process or in memory function can have consequences on orientation.

According to Luria in 1994, the attention process also has an important role, which is to ignore the other stimuli that arrive, select the most important ones and, most importantly, maintain permanent control. If there were no inhibition of stimuli, the information would be too much that no activity would be possible. Attention has a volume which is the number of signals which can be maintained in a lucid consciousness and thus acquire a dominant character.

Memory is a mechanism which allows us to preserve the information that was transmitted by a signal after the action has been suspended (Ostrosky et al. 2012), thanks to memory we can store experiences and perceptions. Memory is an aspect that is too important for the daily life of the human being, since it reflects past experiences, an example is the acquisition of language.

According to Azcoaga (2006), language is a differentiating physiological system in which, combined, proprioceptivetype afferences of the respiratory muscles and phonation, auditory, tactile, vibratory and other input participate harmoniously. Afferent stimuli from various motor systems also intervene: those corresponding to the neuromuscular groups of the larynx, tongue, jaw, and respiration. Also involved are the sections of motor coordination that regulate the sequence of all these neuromuscular activities.

According to Portellano et al., (2007), executive functions are a set of cognitive skills that, thanks to these functions, complex problem solving is carried out, other functions are also involved such as anticipation, setting goals, designing plans, initiating activities or operations. mental, self-regulation, precise selection of the appropriate behaviors for each occasion and the organization of time. 
The results of Ferreres \& López (2009) indicate that the reading is carried out through two procedures, one lexical in which the letters activate the representation of a previously known word, that is, sequences of letters already known, in order to activate its meaning. The semantic and non-lexical path is a more complex process in which the segmentation of letter sequences into appropriate units is first carried out in order to apply the phonemegrapheme conversion rule and semantic activation occurs after said phonological assembly.

In 2012, Díaz \& Price concluded that today writing is considered a communicative process which is made up of specific cognitive and social variables.

Next, with the calculation, the number sense is the one that allows us to perceive the number of objects that make up a group and in this way distinguish between whether there are many or few objects (Serra, Pérez, \& Lachica, 2010).

\section{Substance dependence according to DSM-V}

González (2011), affirms that drug dependence is the mental or sometimes physical state caused by the reciprocal action between a living organism and a drug, which is characterized by behavioral modifications and other reactions that lead to an impulse to take the drug. continuously or periodically in order to experience its psychic effects.

Addiction is a disease, considered a voluntary act which cannot be controlled, it is repeated with short intervals and addictions are usually accompanied by adverse consequences on personal life, family and work environment.

According to the American Psychiatric Association (APA, 2013) A dependence on toxic substances is created when the subject continues to consume despite the appearance of significant problems related to it.

Alcoholism is considered a disease which is chronic, progressive and fatal, it is characterized by tolerance and physical dependence on alcohol, there is also the presence of organic or pathological changes (Boet, 2000).
In 2005 Arias concluded that what happens in the brain when a person consumes alcohol, mainly is that when alcohol has a direct effect on the body it is because alcohol is capable of crossing the blood-brain barrier by $90 \%$, it can also interfere with nerve action potentials. The anesthetic effect generated by alcohol is produced by the inhibitory action on the NMDA receptors of the neurotransmitter glutamate, which has an excitatory power in the brain.

action $\begin{gathered}\text { Amphetamines or substances of similar } \\ \text { include amphetamine, }\end{gathered}$ dextroamphetamine and methamphetamine, also include substances that are structurally different, but have a similar action to amphetamine such as methylphenidate or diet pills (anorectics) (American Psychiatric Association, 2013).

According to Villarreal \& Córdoba (2019), the use of methamphetamines leads to some alterations in the brain, such as, for example, the use of methamphetamines can generate consequences in the synapse of dopaminergic pathways thanks to an excessive expulsion of dopamine, this increases the CNS stimulating activity.

According to Mena, Dörr, \& Viani, (2013) some of the consequences of consuming cannabis in adolescents have been shown to have lower cognitive abilities associated with the learning process such as attention, concentration, hierarchy, visuospatial integration and memory visual. Another type of alterations are those that affect the functions of the prefrontal cortex, such as the planning capacity and the inhibition of responses.

The results of the National Institute on Drug Abuse (2013) indicate that the way in which Cannabis acts in the brain is thanks to its main active substance which is deltatetrahydrocannabinol (THC), it passes first to the lungs and then It quickly passes into the bloodstream, where it is transported to the rest of the body including the brain, when Cannabis is smoked, much more THC is deposited in the bloodstream, unlike if it is ingested orally either through food or drink. 
Deltatetrahydrocannabinol binds to cannabinoid receptor nerve cells which influence pleasure, memory, thought, concentration, movement, coordination, and sensory perception and time. Chronically consuming marijuana can alter the loss of neurons in the hippocampus, which reduces its ability to learn new information.

In 2015, Damin \& Grau have concluded that cocaine belongs to the group of drugs that stimulate the central nervous system,

The American Psychiatric Association (2013) indicates that cocaine is a natural substance produced by the coca plant. Creating dependence on cocaine can be shorter in periods of time thanks to its powerful euphoric effects, the main characteristic of dependence. This substance is to refrain from consuming it when the person has cocaine within reach, thanks to the fact that its effect is short, people tend to administer frequent consumptions to maintain a euphoric state.

Cocaine causes damage to the brain according to Madoz, Ochoa \& Martínez (2009), which can develop at different levels and by various mechanisms, the most common being a consequence of the direct vascular effect of the substance, the patient being the most prone to an ischemia mainly and more rarely a hemorrhage.

\section{NEUROPSI}

Brief neuropsychological evaluation in Spanish.

It is a brief, reliable and objective instrument that allows to evaluate a wide spectrum of cognitive functions in psychiatric, geriatric, neurological patients, patients with various medical problems. Its administration time ranges from 25 to 30 minutes approximately.

The rating system provides qualitative and quantitative data. With the independent data of each cognitive ability, an individual profile is obtained that indicates the abilities and disabilities of the subject in each of the evaluated areas which are orientation, attention and concentration, memory, language, visoconstructive processes, executive functions, reading, writing and calculation.
This evaluation has different ranges of ages and schooling for the people who will be evaluated, the ages range from 16 to 30,31 to 50,51 to 65 and 66 to 85 years, in terms of schooling it goes from 0,1 to 4,5 to 9 and more than 10 years of study (Ostrosky, et al. 2000).

\section{Research methodology}

The present study is exploratory, nonexperimental, observational and crosssectional, with a descriptive statistical analysis.

The complex variable, neurocognitive functions, was analyzed to know the prevalence of altered neurocognitive functions, in addition the signal variables of: age, gender and education were considered.

For the statistical analysis of the characteristics of the studied population, measures of central tendency and dispersion were used.

As inclusion criteria, patients attending the Alcoholics Anonymous First of May group in Durango, Dgo, who wished to participate in the study and had signed a prior informed consent letter, were considered, therefore those patients who did not wish to participate were excluded; As elimination criteria, those patients who decided to withdraw their informed consent at any time during the evaluation, or those who still had active drug use, were discarded; Due to this criterion, 3 cases were eliminated, leaving a total of 20 valid cases.

\section{Procedure}

The participants were patients who attend a group of alcoholics anonymous 24 hours called Primero de Mayo from the city of Durango. Data collection was carried out during the period of September 2020, culminating at the end of September of the same year.

Prior signing of the informed consent was obtained in accordance with the official Mexican standards 004-ssa3-2012 of the clinical record and 040-ssa2-2004 in the matter of information, we proceeded to the application of the instruments for the collection of data and interpretation of the results. 
For the study of neurocognitive functions in patients, the NEUROPSI BRIEF neuropsychological evaluation was used, it is a short, reliable and objective instrument that allows to evaluate a wide spectrum of cognitive functions.

It consists of 6 sections that evaluate neuropsychological functions, which are the orientation section with 3 items, attention and concentration with 3 items, the memory section with its coding and evocation memory subsections which consist of 5 items between the two subsections, the language section consists of 5 items, the reading and writing section consists of 3 items and finally the conceptual and motor executive functions section which consists of 7 items.

Qualified by the following values: high normal, normal, moderate and severe. Each item is valued according to each subarea and according to the age range and level of education of each subject evaluated.

The identification of the signal variables and academic performance (gender, age and school average) was obtained through the application of a clinical survey.

The statistical analysis of the information obtained was carried out using the Excel software computer program.

\section{Results}

The sample consisted of 20 people who attend the 24-hour group Alcoholics Anonymous "May Day", of which 3 (15\%) were women and 17 $(85 \%)$ were men. The average age of the participants is 33 years, the minimum being 20 years and the maximum 69 years. The school grade of the people who participated in the evaluation was: 4 people finished primary school, 8 people finished secondary school, 6 high school and one person finished university.

To find out the percentage of people who used drugs and how often they were used, a survey was carried out which was found in the medical history, where it was asked what type of substances each person consumed and how often they were consumed.
Which resulted in the substances most consumed 4 or more times a week occupying the first place has been alcohol, being the substance most consumed by 11 people and then amphetamines in second place being the substance most consumed in the week per 9 people and the least ingested substances within a week are hallucinogens and inhalants.

The substances consumed less frequently from one to two times a month by the people evaluated, continues to be alcohol, still in the first place, being 4 people who use alcohol from one to two times a month and then inhalants follow obtaining a result in which two people are the ones who use inhalants a few times a month, while all other substances such as hallucinogens, amphetamines, cannabis and cocaine are all in the lowest consumption.

Next, graphic 1 of drug use on the evaluated people is shown, which was obtained through the clinical history that was taken before starting the evaluation.

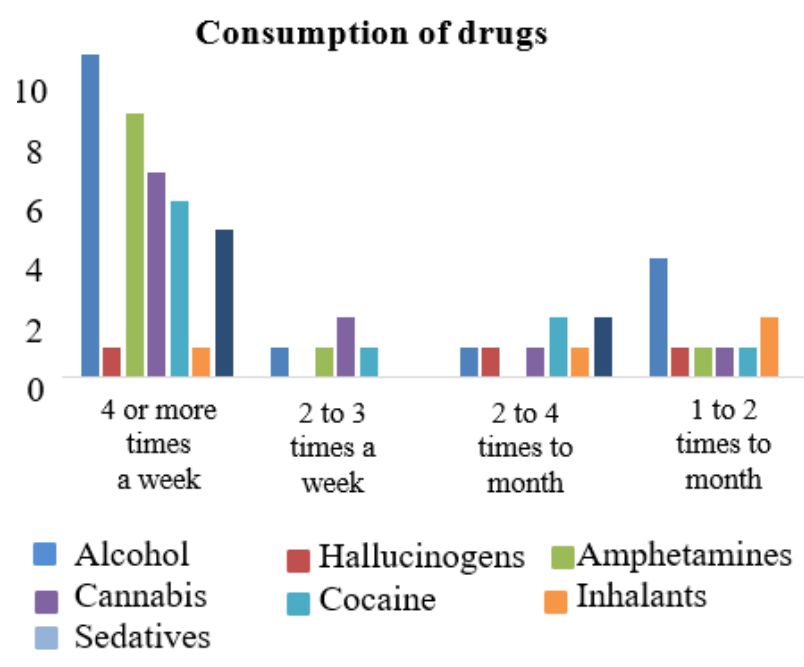

Graphic 1 Consumption of drugs

Regarding the results obtained from the neuropsychological evaluation NEUROPSI, they were obtained thanks to all the areas and subareas evaluated. Where we can see that the highest percentage was $40 \%$ of people with a normal result, then $15 \%$ with a mild result, $25 \%$ with a moderate result and finally $20 \%$ with a severe result, thus adding the mild, moderate and severe results, we have that $60 \%$ of the population presents alterations in neurocognitive functions (see table 1). 


\begin{tabular}{|l|r|r|}
\hline & Persons Percentage \\
\hline Normal & 8 & $40 \%$ \\
\hline Mild & 3 & $15 \%$ \\
\hline Moderate & 5 & $25 \%$ \\
\hline Severe & 4 & $20 \%$ \\
\hline
\end{tabular}

Table 1 Neuropsi results

The reliability of the results obtained using the short neuropsychological battery in Spanish NEUROPSI was 0.05, which shows a good reliability value, likewise using the parametric $t$ student test used in the study to identify the relationship between the data obtained; the greater the consumption of toxic substances harmful to health, the greater the impairment of neurocognitive functions, mainly observed in the areas of attention and concentration, memory, executive functions and reading.

Graphic 2 shows the results obtained from the areas evaluated using the Neuropsi neuropsychological battery. According to the score of each evaluation: accommodating the percentages from highest to lowest score, firstly there is orientation with $98.33 \%$ of correct answers, then there is language with a percentage of $86 \%$, writing with $85 \%$, coding with $82.7 \%$, executive functions with $77 \%$, evocation memory with $73 \%$, attention and concentration with $59.81 \%$ and in the last place is reading with $53.3 \%$.

Graphic 2. Percentage by Neuropsi areas

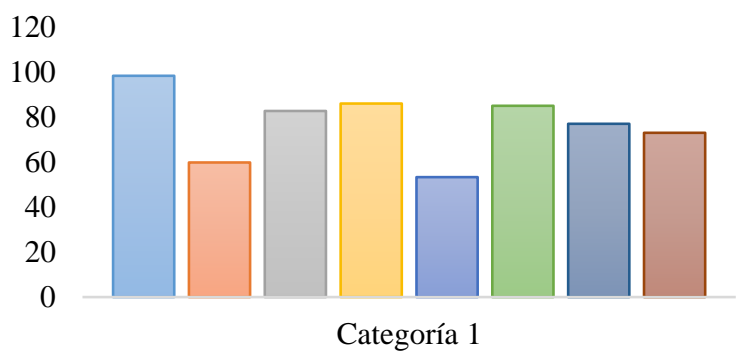

$\square$ Orientation

$\square$ Attention and concentration

$\square$ Encoding memory

$\square$ Language

$\square$ Reading

$\square$ Writing

$\square$ Executive functions

$\square$ Evocation memory

Graphic 2 Percentage by Neuropsi areas
Next, regarding the specific objectives, graphic 3 shows the prevalence of altered neurocognitive functions in patients with alcohol dependence, with dependence on cocaine, methamphetamine and marijuana. In this graph you can see the most affected functions, which are: reading, attention and concentration, having in common that they are affected by the four different toxic substances evaluated. It is observed that the drug with the greatest alteration is methamphetamine, followed by alcohol, then cocaine and marijuana are found, marijuana being the drug with a little less alteration according to the results of the Neuropsychological Battery, NEUROPSI.

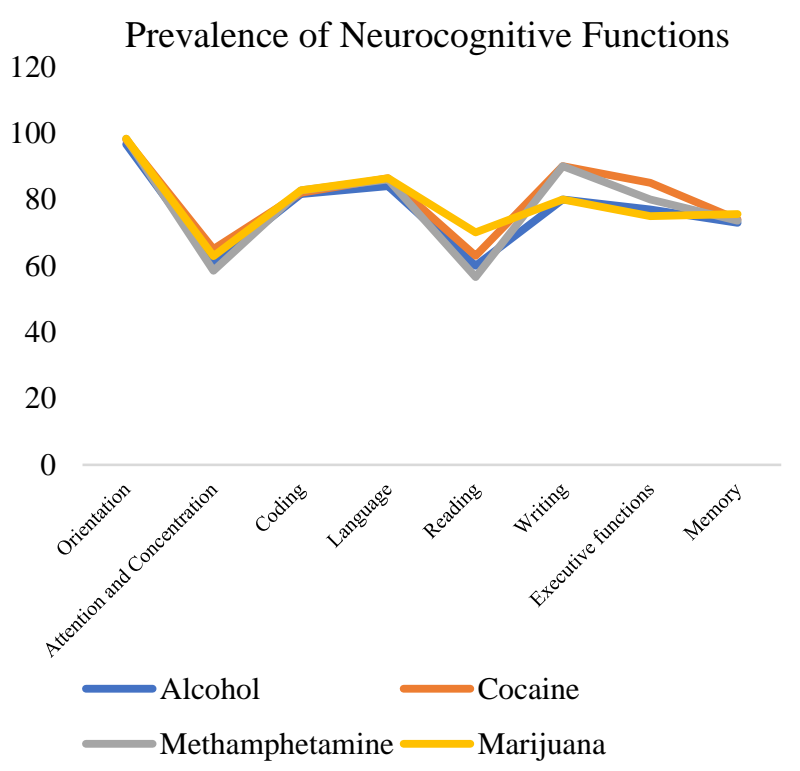

Graphic 3 Prevalence of Altered Neurocognitive Functions

It should be mentioned that the results in this population cannot be extrapolated, they cannot be taken as a general data since it is only a small sample of a place, it would be necessary to make several comparisons with other institutes to see how the cognitive functions are found.

\section{Conclusion}

According to the standards established by Ostrosky, Ardila and Rosselli of the Neuropsi neuropsychological evaluation, the results obtained showed an average of $40 \%$ of the population with a normal parameter, $15 \%$ of the population with a mild result, $25 \%$ with a moderate result and $20 \%$ a severe result. 
Based on the evaluation, one of the areas with a lower percentage was the area of reading with an average of $53.3 \%$ of correct answers, reading can be related to learning and according to Arias in 2005 in his work "Physiological Reactions and neurochemicals of alcoholism "mentions that when there is excessive alcohol consumption it is more likely that neurological pathologies appear such as acute and chronic dysfunction of the brain which produces disorders in the central nervous system causing alterations in complex intellectual functions where the calculation, the understanding and learning.

Another drug that also harms this area is cocaine, as mentioned by Madoz, Ochoa, and Martínez, in their article Cocaine consumption and neuropsychological damage that cocaine causes damage to the brain which can develop at different levels and by various mechanisms, the The most common result is the direct vascular effect of the substance, affecting cognitive functions such as memory, learning and attention.

In the attention and concentration section, which obtained a slightly higher percentage with 59\% correct answers, it coincides with the fact that most drugs have an impact in this area, but mainly marijuana and cocaine are the ones that the authors mention the most.

As is the case of the National Institute on Drug Abuse in 2013 in its article called Marijuana abuse where it mentions that deltatetrahydrocannabinol, which is a compound of marijuana, adheres to cannabinoid receptor nerve cells, these exert influence on the pleasure, memory, thought, concentration, movement, coordination.

According to cocaine, Madoz, Ochoa and Martínez agree that people who use cocaine for a long period of time have a low performance of attention, as well as sustained and sustained attention.
Memory is one of the most important neuropsychological functions, which is affected by the consumption of all drugs without exception, as mentioned above in the case of marijuana and cocaine, in this evaluation the memory section obtained a total of $73 \%$ of answers answered correctly, and to begin with according to Arias, R. alcohol generates an anesthetic effect which is produced thanks to the inhibitory action of the NMDA receptors of the neurotransmitter glutamate, this is an excitatory neurotransmitter and thanks to consumption alcohol produces modifications in the neuronal mechanism of the hippocampus and the cortex that are very important structures for memory and this can generate alterations in memory.

Based on Villareal and Córdoba, the use of methamphetamines leads to some alterations in the brain which also have repercussions on memory, for example, it can generate consequences in the synapse of dopaminergic pathways thanks to an excessive expulsion of dopamine, this increases the CNS stimulating activity. There have been studies of people who used methamphetamine for a large part of their lives and affected brain areas were observed which are related to memory and emotion.

It can be concluded that in the 24-hour group of alcoholics anonymous "May Day" users who participated in the study, it was obtained that $40 \%$ are in a normal parameter according to the NEUROPSI evaluation scale while $60 \%$ presented neurocognitive alterations in the areas of attention and concentration, memory and reading comprehension, however, it is recommended to expand the sample with a greater number of people who are in different recovery centers. Subsequently, propose to create drug use prevention campaigns at the secondary and high school level since most of the participants were vulnerable during that school stage, being one of the main factors of school dropout.

\section{Thanks}

A sincere thanks to the 24-hour group of Alcoholics Anonymous May 1st for the facilities granted to carry out this research work, as well as to the teacher Angel Ontiveros and the research participants. 


\section{Referencies}

American Psychiatric Association (2013). Diagnostic and statistical manual of mental disorders (5a. ed) Washington, DC EE. UU.

Arias, R. (2005). Reacciones fisiológicas y neuroquímicas del alcoholismo. PERSPECTIVAS EN PSICOLOGÍA. Vol. I. (No. 2) pp. $138-147$.

Azcoaga, J., Bello, J., \& Citrinovits, J. (2006). Los retardos del lenguaje en el niño. España: Paidós Ibérica, S.A.

Bolet. M. (2000). LA PREVENCIÓN DEL ALCOHOLISMO EN LOS ADOLESCENTES. Rev Cubana Med Gen Integr 16(4):406-9.

Centros de Integracion Juvenil. (2018). https://www.gob.mx/salud/cij/acciones-yprogramas/programa-de-tratamiento-yrehabilitacion-117988

Damin, C., \& Grau, G. (2015). Cocaína. Acta Bioquímica Clínica Latinoamericana, 49 (1), 127-134

https://www.redalyc.org/articulo.oa?id=535412 85011

Díaz, C., \& Price, M. (2012). ¿Cómo los niños perciben el proceso de la escritura en la etapa inicial?. Estudios Pedagógicos,XXXVIII. ( ${ }^{\circ}$ $1)$ : 215-233. https://scielo.conicyt.cl/pdf/estped/v38n1/art13. pdf

EL RICON DEL CUIDADOR. (s.f). CAPACIDADES COGNITIVAS. https://www.elrincondelcuidador.es/blog/capaci dades-cognitivas.

Ferreres, A., \& López, C. (2009). LAS ALEXIAS FONOLÓGICA, DE SUPERFICIE Y PROFUNDA EN HISPANOHABLANTES Y LOS MODELOS DE DOBLE RUTA. Prensa Médica Latinoamericana, III (2): 161 - 176. http://www.scielo.edu.uy/pdf/cp/v3n2/v3n2a05. pdf

Franco, V. (2004) Neurociencia del consumo y dependencia de sustancias psicoactivas. Washington: World Health Organization
GOBIERNO DE MEXICO. (2019). Informe mundial de drogas 2019. https://www.gob.mx/salud/articulos/informemundial-de-drogas-2019.

González, M (2011). Bases neurológicas de la dependencia a sustancias psicoactivas desde la mirada social. Revista Costarricense de Psicología, $30 \quad$ (45-46), 77-94. https://www.redalyc.org/articulo.oa?id=476748 709001

Instituto Nacional de Rehabilitación Luis Guillermo Ibarra Ibarra. (2017). Licenciatura en Comunicación Humana. https://www.inr.gob.mx/e40.html

Luria, A. (1994). ATENCION Y MEMORIA. Barcelona: Ediciones Martínez Roca, S.A.

Madoz, A., Ochoa, E., \& Martínez, B. (2009). Consumo de cocaína y daño neuropsicológico. Implicaciones clínicas. Medicina Clínica. 132(14):555-559

Mena, I., Dörr, A., \& Viani, S. (2013). Efectos del consumo de marihuana en escolares sobre funciones cerebrales demostrados mediante pruebas neuropsicológicas e imágenes de neuroSPECT. Salud Mental. (No. 36): 367 - 374

National Institute on Drug Abuse. (2013). Abuso de la marihuana. https://www.drugabuse.gov/sites/default/files/m arihuana_rr_sp_2013.pdf

NIDA. (2019, noviembre 15). Enfoques de tratamiento para la drogadicción. https://www.drugabuse.gov/es/publicaciones/dr ugfacts/enfoques-de-tratamiento-para-ladrogadiccion.

O.M.S. (1992) CIE-10. Trastornos Mentales y del Comportamiento. Décima Revisión de la Clasificación Internacional de las Enfermedades. Descripciones Clínicas y pautas para el diagnóstico. Ginebra, 1992.

Organicismo Mundial de la Salud. (2018). Alcohol. https://www.who.int/es/newsroom/fact-sheets/detail/alcohol.

Ostrosky, F., Gómez, M., \& Matute, E. (2012) Neuropsi Atención y Memoria. México: Manual Moderno 
Ostrosky-Solis, F., Ardila, A., \& Rosselli, M. (2000). Evaluación del funcionamiento cognoscitivo: Neuropsi evaluación neuropsicológica breve en español : manual e instructivo. México, D. F.: Publingenio

Portellano, j., Díez, A., \& García, J. (2007). El test de las anillas (TA), un nuevo instrumento para la evaluación de las Funciones Ejecutivas. MAPFRE MEDICINA, Vol. 18 (No.1) 1 - 10

Ríos, J., Gurrola, A., y Hernández, J. (2017). Análisis descriptivo por genero de las funciones neurocognitivas en alumnos de la Licenciatura de Medicina de la Facultad de Medicina y Nutrición de la UJED. Revista de Ciencias de la Salud, Volumen 4 (13): 1 - 13. https://www.ecorfan.org/bolivia/researchjournal s/Ciencias_de_la_Salud/vol4num13/Revista_Ci encias_de_la_Salud_V4_N13_1.pdf

$\begin{array}{lcr}\text { SECRETARIA } & \text { DE SALUD. } \\ \text { CONSUMO } & \text { (2017). }\end{array}$
https://www.gob.mx/cms/uploads/attachment/fi le/234856/CONSUMO_DE_DROGAS.pdf

SECRETARIA DE SALUD. (2017). ENCUESTA NACIONAL DE CONSUMO DE DROGAS, ALCOHOL Y TABACO 2016 - 2017. https://www.gob.mx/cms/uploads/attachment/fi le/246052/hojasresumen_Alcohol-V3.pdf

Serra, J,. Pérez. M., \& Lachica J, (2010). Bases neurales del procesamiento numérico y del cálculo. Rev Neurol, 50: 39-46.

Sociedad Nacional de Esclerosis Múltiple. (s.f.). Tome el Control de su Esclerosis Múltiple.https://www.nationalmssociety.org/Na tionalMSSociety/media/MSNationalFiles/Spani sh/Problemas_cognitivos.pdf

Valdevila, F., Jaramillo, J., \& Caecelén, R. (2020). Relación entre el consumo de drogas psicoactivas y el deterioro cognitivo en pacientes ecuatorianos drogodependientes. Correo científico médico. (No.24): 1 - 16.

Villarreal, F., \& Córdoba, L. (2019). Efectos de las anfetaminas en el sistema nervioso. Presencia Universitaria. (No.14): 85 - 91.
SHADE-CASAS, Helue, ONTIVEROS-VARGAS, Angel Adrian, HERRERA-VARGAS, Isela Vanessa and SALAS-NAME, Sagrario Lizeth. Neurocognitive functions evaluation by the neuropsychological NEUROPSI battery in patients attending "AA" by drug and alcohol consumption. Journal of Health Sciences. 2021 